\title{
13. What types of Chinese ODI activities are most prone to political intervention?
}

\section{Bijun Wang and Xiao He}

China's outward direct investment (ODI) activities have increased rapidly. At the same time, Chinese enterprises are frequently encountering obstacles as they invest in overseas markets. Although investment liberalisation and promotion remain mainstream policies in overseas markets, more and more countries are strengthening their regulation of foreign investment.

This chapter studies Chinese ODI activities that encounter political obstacles in host countries. Above all, two concepts should be clarified. First, what does it mean to 'encounter obstacles'? In this study, it means Chinese enterprises that have failed to complete their ODI projects for various reasons and it does not cover those that have completed their investment projects (even if their investment has proved a failure or incurred losses). Second, what are the 'political factors' in host countries? These are factors related to the activities of the host country government that can influence foreign investors, including national security reviews, changes of government, policy changes, nationalisation and government default.

Chinese enterprises should draw lessons from their overseas investment activities so that the high price they have paid can be transformed into precious lessons for the future. This chapter conducts theoretical analysis of the political influence of foreign investment on host countries and reactions to it. Meanwhile, based on 22 cases of attempts by Chinese enterprises to invest overseas that encountered political obstacles in the host country and 432 cases of Chinese enterprises successfully completing their overseas investment projects during the period 2005-15, the chapter attempts to conduct empirical analysis to reveal the important factors affecting Chinese ODI before putting forward solutions to the challenge.

\section{Political influence of foreign direct investment on host countries and counter reactions}

Foreign direct investment (FDI) activities are often politicised because they can have multiple impacts on the domestic politics of host countries. First, whether intended or not, investing countries may acquire the capability to menace the national security of host countries through ODI; moreover, the more complicated 
the international environment of the host country, the more serious are the potential risks brought by ODI. Second, ODI can bring new rules and practices for corporate operation, which can trigger political debates regarding standards of 'market behaviour' in host countries. Third, ODI may also lead to structural changes in the incomes of various social groups in the host country, which impacts on their vested interests and reshapes their domestic political alliances (Kerner 2014). To sum up, since ODI can bring risks to national security and controversies about business standards and trigger changes in the incomes and political structures of host countries, the investing countries are likely to face political counterreactions to their investment activities.

\section{ODI and national security}

ODI can easily become intertwined with issues of national security, and may prompt direct political counterreactions through the host country's review of national security. Although the Organisation for Economic Co-operation and Development (OECD) has consistently tried to clearly define 'national security' and establish principles for its review—such as nondiscrimination, transparency and predictability, regulatory proportionality and accountability - the process of such reviews remains quite opaque (OECD 2009: 1-4). Although quite a few countries have set investment and industry thresholds to trigger national security reviews, the process involved remains covert and is subject almost entirely to the discretion of the relevant agencies in the host country (Kirchner 2012).

ODI can bring national security risks because of the differences in national policy goals between the investing and the host countries, and also because investing countries can take control of the strategic assets of host countries through direct investment in fields such as energy, telecommunications and infrastructure, and acquire the capability to prevent host countries from achieving their policy goals (Hemphill 2009). History shows such risks exist. In the 1970s, the oil-producing countries in the Middle East made use of the supply of oil to pressure Western countries to change their policies towards Israel. Such moves made the United States unprecedentedly cautious about the large amounts of FDI assets held by oilproducing countries. It therefore established the Committee on Foreign Investment in the United States (CFIUS) in 1975 with a view to examine investment by members of the Organization of the Petroleum Exporting Countries (OPEC) in the United States. After the 11 September 2001 terror attacks in the United States, Dubai Ports World made an attempt to purchase the Peninsular and Oriental Steam Navigation Company (P\&O), prompting the US Government to strengthen its national security review mechanisms and clarify, on the appeal of the Congress, the definition of critical infrastructure; meanwhile, it also adopted the principle of reverse burden of proof in dealing with relevant matters. What is noteworthy 
is that there is not a positive correlation between national security reviews and national policy differences. Developed countries can still use national security as an excuse to restrict investment in some major infrastructure areas by their allies even though they do not have obvious policy differences. For instance, the US Reagan administration stopped the purchase of Fairchild Semiconductor by Fujitsu in 1988, and Japan also made use of a similar mechanism to stop British companies entering its telecommunications industry (Watai 2013).

Scholars and international organisations that support liberalisation of direct global investment have been pushing for a transparent national security review mechanism. For instance, they want a clear definition of the scope of 'sensitive industries' and formulation of unified international review procedures. However, many governments, including the US Government, would like to maintain the current flexible security review mechanism. From the perspective of countries and enterprises that make ODI, there are two issues with the current national security review mechanism, which is dominated by the administrative departments of host countries: given its power of discretion, a government can make use of the mechanism to resist pressure from domestic vested interests; and it can also make use of the mechanism's lack of transparency to serve those interest groups.

\section{Conflict about market rules brought by ODI}

Apart from the issue of national security, ODI flooding into host countries can also lead to the spread of the rules and conventions governing economic activity in the investing countries. If the host and parent countries are in different development phases or have divergent social structures and abide by different economic principles, there can be a conflict in the rules, which is especially evident between developing and developed countries.

Initially, developing countries are the ones most subject to the 'rule shocks' brought by ODI by foreign countries. Foreign enterprises operating in developing countries rely on their business prowess or their own governments to directly or indirectly exert pressure and demand changes to local systems. The laws, conventions and rules of the developing countries receiving ODI are often seen as a source of political risk to modern economic activities and those countries, therefore, are continually required to change their systems to the practices of Western countries or 'raise their political system quality' (Hayakawa et al. 2013). Despite such potential conflicts, developing countries remain attractive to ODI from developed countries; the developing countries, as recipients of ODI, in most cases will opt to accept 'new rules' to satisfy the demands of the capital-exporting countries (Blanton and Blanton 2007). In recent years, the rapid growth of two-way investment among developing countries seems to indicate there is no absolute standard or environment that is 
most attractive for ODI, but the narrower the institutional distance between two countries, the more favourable it is to carry out ODI (Bénassy-Quéré et al. 2007). The dominant position of the developed countries, however, means any rules they favour will be spread to the host country.

However, as FDI by the emerging-market economies increases remarkably, developed countries have also started to face reverse 'standard shocks'. On the one hand, in developing countries such as those in Africa, outward direct investors from emerging-market economies generally are more tolerant of local corruption or 'bad governance', which to an extent offsets the spread of standards favoured by the developed economies (Wood et al. 2014). On the other hand, multinationals from the emerging-market economies, led by China, have sought to acquire strategic resources all over the world (Lu et al. 2010), including in developed countries, which has aroused complaints about 'nonmarket behaviour'. In the eyes of the developed countries, due to their different operational logic, emerging economies' ODI has brought illegitimate competition pressures to enterprises in the host countries. A balance can be struck only by improving the existing rules for market competition and imposing restrictions on enterprises receiving state support.

Currently, to reduce the advantages of state support of some emerging-economy multinationals, developed countries have focused on achieving neutrality in the current stage of rules-based competition and have required the reduction or even elimination of the special treatment enjoyed by state-run and private enterprises (Capobianco and Christiansen 2011). In the eyes of the United States and European countries, the governments of the emerging economies, including the Chinese Government, not only provide multiple policy supports to their own businesses, they also give detailed directions for the overseas operations of those enterprises (Rosen and Hanemann 2013); therefore, rules must be made promptly to address such behaviour. In the negotiations relating to the Trans-Pacific Partnership (TPP) and the Transatlantic Trade and Investment Partnership (TTIP), the European Union has expressed strong opposition to countries:

inducing or ordering State-owned enterprises (SOEs) and enterprises granted special or exclusive rights or privileges (SERs) to engage in anti-competitive behavior, by taking regulatory measures favoring these companies, or by granting subsidies (or measures which have similar effects) to them. (European Commission DirectorateGeneral for Trade 2013)

The United States has also expressed its concern over the abnormal policy support given to, and the 'uneconomic' behaviour of, SOEs and private companies that obey state orders (US Chamber of Commerce and National Foreign Trade Council 2012).

Whether they receive or export ODI, developing countries must face the conflicts brought about by differing sets of rules, and they are often in a disadvantageous position. If, in the first phase of exporting ODI, developed countries aim to spread 
free-trade principles and shape countries to be competitive in the international system by stressing the efficiency of multinationals and state capability in attracting foreign investment (Fougner 2006), they have undoubtedly engaged in a type of gaming that tilts the international economic and trade rules towards cutting direct linkages between the state and enterprises, thus eliminating the emerging economies' advantage in exporting ODI and ensuring the continual spread of free-market principles.

\section{Effects of ODI on distribution and domestic politics}

Apart from conflicts over national security and rule-setting caused by differing economic models, the most direct effect of ODI is changing the income distribution of social groups in the host country. Such changes can also lead to a reshaping of domestic political unions in host countries. However, the academic circle is still divided over what political effects ODI can bring. Those with positive views of ODI believe it can significantly increase demand for labour in the host country and contribute to improvement in labour conditions. Local owners of capital, however, are likely to encounter rising costs and intensified market competition. Therefore, the more democratic a government is, the more positive will be that government's attitude towards ODI (Pandya 2014). In contrast, those with a negative view of ODI hold that both horizontal ODI, targeting the market, and vertical FDI, targeting efficiency, or the comprehensive knowledge-capital model of ODI, may widen labour income gaps and worsen conditions for low-income groups (Lankhuizen 2014). In some extreme cases, ODI will not lead to a rise in wages for any labour groups and only local capital owners will benefit from such investment (Waldkirch 2010). In real-world politics, the ruling group also treats ODI activities differently. For instance, a pro-labour government may encourage ODI inflows that contribute to improvements in workers' wellbeing, while a pro-capital government may encourage ODI inflows that will lower labour costs (Pinto and Pinto 2008). Therefore, the type of political obstacles ODI will encounter is closely related to redistribution in the host country.

Among the many ODI-related indicators, employment security is the one that has the biggest political appeal. However, existing studies are yet to prove whether ODI has a long-term and positive effect on employment security. Most researchers acknowledge that ODI enterprises generally have a competitive advantage and offer higher wages and more stable jobs, but they also stress that this does not necessarily mean there will be an increase in overall social wellbeing (Girma and Görg 2007), because the ODI inflows - especially those with an extensive margin —will have a negative effect on the employment of low-skilled workers in the recipient industry 
(Bachmann et al. 2014). Moreover, not all foreign enterprises have a competitive edge. Some small-scale ODI that is made by private companies in non-export sectors can threaten employment security given the lack of local operational networks (Andrews et al. 2012). Research shows that vertical ODI that has acquired export enterprises is conducive to long-term employment security and overall employment rate growth (Bandick and Görg 2010).

Apart from employment security, income disparity is an equally important political factor. Horizontal comparisons show that the more advanced the technologies of the host country, the less significant will be the effect of ODI on domestic income disparity. This means ODI activities of the same nature will have different effects on income disparity in developed and developing countries. In developed countries, the effect of ODI on widening income disparity is often not very obvious, because in economically developed and technologically advanced countries, foreign enterprises generally play the role of technology receivers, not initiators; as a result, they will not significantly increase demand for skilled workers, nor will they cause income disparity (Bode and Nunnenkamp 2011). Such a characteristic is especially apparent in the United States. In the 1980s, Japan made large amounts of direct investment in the United States, but the investment did not promote industrial upgrading within the United States, nor did it help increase the incomes of highly skilled workers; on the contrary, it increased demand for low-skilled workers and widened income gaps (Blonigen and Slaughter 2001).

Therefore, the effect of ODI on income distribution among different social groups in a host country mainly hinges on the nature of the ODI and the development level of the host country. Groups that have or are likely to see their interests affected will use existing political mechanisms to block the entry and operation of ODI. What needs to be stressed is that, for the United States, its leading role in technology actually provides a more favourable domestic political environment for the entry of ODI. On the one hand, ODI does not mean being more competitive and generally does not lead to significantly intensified competition in the domestic market; on the other hand, foreign investment in the United States is generally not efficiency-driven and seldom involves reduction in numbers of jobs or wages, and therefore does not pose a significant threat to the wellbeing of the local labour force. Therefore, the 'political' challenges facing overseas direct investors in a developed economy such as the United States come mainly from their rivals in acquisitions and the federal government, not from local voters or state governments.

The above analysis points to the three main effects of ODI on the domestic politics of host countries and the subsequent backlash. In most cases, the business rivals of investors making ODI make use of the above factors and political environment to block the entry of competitive ODI. After sorting out the theoretical aspects of the issue, this chapter will carry out analysis using real cases. 


\section{Case studies of China's blocked ODI projects}

The cases of blocked investment in this chapter are projects that have not been completed for political reasons in the host country. Few scholars and institutions have thoroughly investigated such projects carried out by Chinese investors and therefore this chapter collects a total of 22 cases from 2005 to 2015-including cases labelled 'withdraw' in the BVD-Zephyr database; data dubbed 'troubled transactions' in the China Global Investment Tracker system of the American Enterprise Institute and the Heritage Foundation; and cases revealed by media outlets within China and abroad, such as Caixin, Reuters, Bloomberg, the Financial Times, the China Securities Journal, as well as information disclosure on the websites of the companies concerned (see Table 13.1).

\section{Table 13.1 Cases of blocked Chinese ODI projects}

\begin{tabular}{|c|c|c|}
\hline 1 & 2005 & China Minmetals Corporation's bid to buy Canadian metals company Noranda \\
\hline 2 & 2005 & The bid by China National Offshore Oil Corporation to buy US energy company Unocal \\
\hline 3 & 2008 & Huawei's bid to buy US-based 3COM \\
\hline 4 & 2009 & Chinalco's increase in investment in Australia-based Rio Tinto \\
\hline 5 & 2009 & $\begin{array}{l}\text { Northwest Non-Ferrous International Investment Company's investment in US-based } \\
\text { Firstgold Corp. }\end{array}$ \\
\hline 6 & 2009 & PetroChina's bid to buy Canada-based Verenex Energy, Inc. \\
\hline 7 & 2010 & Huawei's bid to buy the wireless equipment business of Motorola \\
\hline 8 & 2010 & Huawei's bid to buy privately owned broadband internet software provider 2 Wire \\
\hline 9 & 2010 & $\begin{array}{l}\text { Tangshan Caofeidian Investment Corporation's investment in US-based EMCORE } \\
\text { Corporation }\end{array}$ \\
\hline 10 & 2011 & Huawei's bid to buy 3Leaf Systems \\
\hline 11 & 2011 & China Shenhua Energy Company Limited's investment in Mongolia's Tavan Tolgoi \\
\hline 12 & 2012 & Chinalco's bid to buy interests in Canada-based SouthGobi Resources Limited \\
\hline 13 & 2012 & Zhongkun Investment Group's tourism development project in Iceland \\
\hline 14 & 2013 & $\begin{array}{l}\text { China North Industries Group Corporation's investment in a copper mining project } \\
\text { in Myanmar }\end{array}$ \\
\hline 15 & 2014 & $\begin{array}{l}\text { China National Arts \& Crafts Group Corporation's bid to buy two platinum assets from } \\
\text { South Africa's Aquarius Platinum }\end{array}$ \\
\hline 16 & 2014 & $\begin{array}{l}\text { China Railway Group Limited's investment in a railway connecting Kyaukpyu in } \\
\text { Myanmar and Kunming in Yunnan Province }\end{array}$ \\
\hline 17 & 2015 & Yantai Taihai Group Co. Ltd's bid to buy Sheffield Forgemasters International \\
\hline 18 & 2015 & $\begin{array}{l}\text { Bid by Chinese consortium formed by GSR Ventures and Oak Investment Partners } \\
\text { to buy Royal Philips NV's LED business, Lumileds }\end{array}$ \\
\hline 19 & 2015 & Tsinghua Unigroup Co. Ltd's bid to acquire US chip storage giant Micron Technology, Inc. \\
\hline 20 & 2015 & China Communications Construction's Colombo Port City project in Sri Lanka \\
\hline 21 & 2015 & Shanghai Pengxin Group Co. Ltd's bid to buy Australian beef producer S. Kidman \& Co. \\
\hline 22 & 2015 & $\begin{array}{l}\text { Cancellation of a successful bid by China Railway Construction Corporation Limited } \\
\text { to build a high-speed railway in Mexico }\end{array}$ \\
\hline
\end{tabular}

Source: Compiled by the authors. 


\section{Characteristics of blocked investment cases}

Cases of blocked acquisitions have the following characteristics (see Table 13.2).

Table 13.2 Characteristics of the cases of China's blocked ODI

\begin{tabular}{|c|c|c|c|c|}
\hline & No. & $\begin{array}{c}\text { Ratio } \\
(\%)\end{array}$ & Value $(\$ m)$ & $\begin{array}{c}\text { Ratio } \\
(\%)\end{array}$ \\
\hline \multicolumn{5}{|l|}{ Ownership } \\
\hline Private & 8 & 36.36 & $7,590.15$ & 11.90 \\
\hline State-owned & 14 & 63.64 & $56,196.81$ & 88.10 \\
\hline \multicolumn{5}{|l|}{ Industry } \\
\hline Agriculture, forestry, animal husbandry, fishery & 1 & 4.55 & 250.00 & 0.39 \\
\hline Mining & 9 & 40.91 & $47,979.01$ & 75.22 \\
\hline Manufacturing & 8 & 36.36 & $9,659.95$ & 15.14 \\
\hline $\begin{array}{l}\text { Among them: telecommunications equipment, } \\
\text { computer and other electronic equipment } \\
\text { manufacturing }\end{array}$ & 5 & 22.73 & $6,324.50$ & 9.92 \\
\hline Construction & 3 & 13.64 & $5,890.00$ & 9.23 \\
\hline Culture, sport and entertainment & 1 & 4.55 & 8.00 & 0.01 \\
\hline \multicolumn{5}{|l|}{ Country } \\
\hline Developing & 8 & 36.36 & $10,497.00$ & 16.46 \\
\hline Mongolia & 2 & 9.09 & $3,800.00$ & 5.96 \\
\hline Myanmar & 2 & 9.09 & $1,070.00$ & 1.68 \\
\hline Mexico & 1 & 4.55 & $3,700.00$ & 5.80 \\
\hline Sri Lanka & 1 & 4.55 & $1,430.00$ & 2.24 \\
\hline Libya & 1 & 4.55 & 460.00 & 0.72 \\
\hline South Africa & 1 & 4.55 & 37.00 & 0.06 \\
\hline Developed & 14 & 63.64 & $53,289.96$ & 83.54 \\
\hline US & 9 & 40.91 & $28,178.30$ & 44.18 \\
\hline Australia & 2 & 9.09 & $19,750.00$ & 30.96 \\
\hline Canada & 1 & 4.55 & $5,346.01$ & 8.38 \\
\hline Iceland & 1 & 4.55 & 8.00 & 0.01 \\
\hline UK & 1 & 4.55 & 7.65 & 0.01 \\
\hline
\end{tabular}

Source: Compiled by the authors.

First, they mainly involve SOEs. In the 22 cases in Table 13.1, 14 are SOEs, accounting for 64 per cent of the total cases; and the value of the deals involved in those 14 cases accounts for 88 per cent of the total value. Among the 14 SOEs, 10 are centrally administered. There are eight private enterprises involved in the 22 cases and four of the cases involve Chinese technology company Huawei-all in the United States: the company's bid to buy 3COM in 2008; its bid to buy 2Wire, a private broadband internet software provider, in 2010; its bid to buy the wireless equipment business of Motorola in 2010; and its bid to buy 3Leaf in 2011. 
Second, mining, telecommunications and construction are the main industries involved in the blocked investment cases. Of the total number of blocked investments, 41 per cent involve investment in mining, accounting for 75 per cent of the total value of the deals involved. They include two coalmining projects, two oil and gas projects and five projects in iron, aluminium, copper and goldmining. Telecommunications is the second most seriously affected industry, accounting for 23 per cent of the total number of the blocked investments and 10 per cent of their total value. Moreover, three cases involve the construction industry, accounting for 10 per cent of the total value of the 22 cases.

Third, most of the investment blocked (84 per cent) was in developed economies, especially the United States, where nine of the cases occurred, accounting for 64 per cent of the total cases in developed economies and 53 per cent of their value. Apart from the United States, investment was blocked in developed economies including Australia, Canada, Iceland and the United Kingdom. China has encountered relatively fewer hurdles in developing markets, where cases of its investment being blocked account for 36 per cent of the total 22 cases and 16 per cent of the total value. Among the cases of blocked investment in developing countries, two were in Mongolia and Myanmar, and one each in Mexico, Sri Lanka, Libya and South Africa.

\section{Analysis of reasons for blocked investment}

Analysis of the 22 cases involving Chinese ODI shows that national security, conflict over rules and distribution effects are the factors behind investment being blocked. Among these, national security is the most frequently cited factor and has been used to block investment in both developed and developing countries. Cases of blocked investment arising from conflicting market rules have occurred mainly in developed countries and are largely included in the scope of a national security review. In terms of distribution effects, Chinese investors encounter direct blocks arising from local political factors in developing countries, while in developed countries, the blocking often takes effect through a national security review.

\section{National security}

As mentioned earlier, national security is quite a blurred concept and different countries may have different explanations and apply the concept in different manners. For CFIUS, national security includes four key factors. The first is crucial infrastructure, including agriculture and food, national defence industries, energy, public health and health care, banking and finance, water, chemical products, business facilities, dams, information technology, telecommunications, postal services and transportation. Second are key technologies, mainly those closely 
related to national security. Third are key locations within the United States or areas close to key infrastructure. Fourth are enterprises and capital backed by foreign governments. The CFIUS categorisation is quite typical; in the cases of blocked Chinese investment, the second and the third factors can each constitute a reason for refusing the investment, while the first and fourth factors are often cited together.

\section{Key technology}

In Case No. 2 (Table 13.1), the China National Offshore Oil Corporation (CNOOC) proposed acquiring US-based oil company Unocal in 2005, which aroused strong opposition in US political circles. The US House of Representatives voted 398 to 15 to pass a resolution protesting against the deal and called on then president George W. Bush to review the bid under the CFIUS mechanism, citing threats to national security. The main concern was that Unocal's advanced submarine surveying and mapping technology could be acquired by CNOOC to assist China's submarine technology development. In Case No. 17, the Yantai Taihai Group Co. Ltd's bid to buy Sheffield Forgemasters International was blocked by British authorities. Sheffield Forgemasters International forges precision components for manufacturing of military aircraft engines in Europe; it is also a supplier of heavy forging parts for the construction of surface ships in Europe. As a result, the United Kingdom was concerned that the transfer of the controlling shares of the company to a Chinese enterprise would ultimately lead to the disguised transfer of key military technology to China.

\section{Geological locations}

In Case No. 5, after the Northwest Non-Ferrous International Investment Company, which belongs to the Northwest Non-Ferrous Geological Survey Bureau, announced its planned investment in the US-based Firstgold Corp. in 2009, the CFIUS suggested the Chinese company drop its plan, citing some of Firstgold's assets in the State of Nevada that are close to Naval Air Station Fallon, which is a 'key location'. Similarly, in Case No. 21, Shanghai Pengxin Group Co. Ltd's bid to acquire a cattle farm was blocked by Australia's Foreign Investment Review Board; an important reason for the blocking was that half of the property sits within the weapons testing range of the Woomera Prohibited Area in South Australia.

\section{Sensitive industry and foreign government backing}

In Case No. 2, the CNOOC sought to acquire US oil producer Unocal in 2005. On the one hand, Sino-US trade relations were soured by bilateral trade frictions and the United States had been pressuring China on issues such as renminbi appreciation and China's fulfilment of its World Trade Organization (WTO) commitments; on the 
other hand, the United States at that time attached utmost importance to energy security. As a result, CNOOC's purchase plan triggered an explosion of concern among US politicians and Congress even voted to demand that the government investigate the real motives of the Chinese side in the bid. In Case No. 8, Huawei offered to purchase 2 Wire, a US private broadband internet software provider, at a time when the United States and the international community attached great importance to internet security; meanwhile, there had been a series of accusations that China-based hackers had attacked government and corporate websites in other countries to steal crucial information. Yu Chengdong, then chief marketing officer of Huawei, told the media that Huawei had failed to grasp the opportunities in the North American markets at a time when political factors played a relatively small role in influencing corporate decisions. If it had grasped the opportunities at that time, he said, Huawei may have become a major supplier to the North American markets and it would have been much easier to solve the problems it faced (Southern Metropolis Daily 2011). In Case No. 10, Huawei did not encounter major technological challenges in its bid to purchase 3Lead, but the CFIUS ultimately suggested it withdraw its bid due to the company's alleged links with the Chinese military. In Case No. 4, when Chinalco proposed increasing its investment in Rio Tinto, there were accusations that Chinalco was controlled by the Chinese Government and claims that 'China should not be allowed to own Australia'. The Australian Government bowed to pressure and repeatedly postponed the approval of the bid. In the end, Rio Tinto unilaterally cancelled its agreement with Chinalco and announced the formation of an iron ore joint venture with BHP Billiton Limited (now BHP). But the competition authorities in Australia turned this idea down, and Rio Tinto and BHP are fierce competitors in iron ore today.

All in all, national security is a political concept and therefore any review of it is bound to be discriminatory. For instance, in Case No. 5, also situated close to Naval Air Station Fallon are the operations of other foreign mining companies_-such as Canada's Barrick Gold Corporation and Australia's Rio Tinto-some of which are even closer to the station than Firstgold. In practice, there are no unified criteria for conducting national security reviews targeted at foreign investment and it is still up to the discretion of the relevant administrative departments in the host countries.

Apart from developed countries such as the United States, Canada and Australia, Chinese enterprises have also encountered investment blocks citing national security concerns in developing countries. In Case No. 6, PetroChina offered to purchase Verenex, a Canada-based energy company, whose business is mainly in Libya, with 86.3 per cent of its oil output belonging to the Libyan Government. However, the Libyan Government refused to approve the acquisition offer, citing concerns about 'excessive control by China'. In Case No. 12, Chinalco planned to acquire some shares of the Canadian SouthGobi Resources, whose assets are mainly in Mongolia; the Mongolian authorities cancelled some of SouthGobi's exploration and mining certificates, citing national security threats, and Chinalco was forced to withdraw the offer. 


\section{Market rules}

Currently, although developed countries have attached increasing importance to the 'market neutrality principle', there has also been an increase in criticism of Chinese enterprises for enjoying certain privileges, although there are yet to be any cases of investment being blocked solely due to 'competition advantage'. In contrast, suspicions that Chinese enterprises conduct 'noncommercial activities' are an important factor behind the blocking of the activities of Chinese enterprises abroad. For instance, in Case No. 2, in which the CNOOC offered to acquire Unocal, Case No. 4, in which Chinalco proposed increasing its investment in Rio Tinto, Case No. 8, in which Huawei offered to acquire 2Wire, and Case No. 10, in which Huawei offered to acquire 3Lead, national security was cited as the reason for the blocking of those deals. It is considered a national security issue because the governments and societies of those developed countries, such as the United States and Australia, suspect that Chinese enterprises carry out investment activities with noncommercial motives, such as influencing the foreign policy of host countries, making strategic arrangements and ensuring energy supply for China. Before the principle of competition neutralityincluding the principle of restricting the activities of SOEs and other privileged enterprises-plays a larger role in ODI reviews, it can be said that market rules have become part of the national security factor.

\section{Distribution effect and domestic politics}

China's ODI, due to its huge scale, often has a major bearing on domestic industrial development and wealth distribution in developing countries, especially those small and mid-sized countries with problematic governance and serious social division, thus triggering fierce domestic political strife. In developed countries, China's technology, market and branding-oriented investment activities generally will not have a significant impact on overall social interest distribution and the political landscape. Chinese enterprises will face blocking from a small number of local rivals whose interests are damaged by Chinese investment; these groups may make use of, or even manipulate, a special political agenda to block investment from China.

In developing countries, China's ODI projects are often seen as offering political and economic support for the incumbent government and thus are prone to fierce backlash from opposition forces. China's investment in Myanmar is a case in point. In Cases No. 14 and No. 16, the investment agreements signed by Chinese investors with the country's military government were cancelled after the country initiated democratic reforms. In carrying out their investment activities, Chinese enterprises have prioritised winning support from host country governments and have failed to understand and attach importance to social changes and the appeals of ordinary citizens in the host country; as a result, there have been repeated protests organised by local people and political organisations against Chinese investment. In Case No. 20, China had a close relationship with the Mahinda Rajapaksa Government of 
Sri Lanka, but after the country's power shift, the government of the new President, Maithripala Sirisena, immediately announced the cancellation of the Colombo Port City project involving China Communications Construction Group and subjected it to an investment review. During the election process, Sirisena and the opposition party had argued that the interest rates on loans for the project were too high and the environment would be damaged; they also claimed that only Rajapaksa and a small group of people would benefit from the project. In Case No. 22, an international consortium led by the China Railway Construction Corporation Limited successfully won the bid to build a high-speed railway connecting Mexico City and Querétaro state in Mexico. However, three days later, the project was cancelled; one important reason offered was that the four companies cooperating with the Chinese enterprise were 'overly close' to the ruling party, and the opposition party accused them of engaging in unfair deals. Conflicts arising from the distribution of benefits are not confined to developing countries. In Case No. 13, the Zhongkun Investment Group-at the invitation of the Government of Iceland-offered to acquire 300 square kilometres of land for tourism and ecological development. Due to partisan differences, however, the country's internal affairs ministry rejected the deal, citing procedural problems.

In developed countries, Chinese enterprises may face competition from their local rivals, who often make use of election politics to thwart investment and acquisitionsas in Australia. There are two main political forces in Australia-namely, the Australian Labor Party and the Liberal-National Party Coalition. The country holds general elections every three years. Such a tight election schedule means the ruling party must be especially mindful of public opinion, while dealing with criticisms from the opposition party. In Case No. 4, Chinalco's competitor BHP is the second-largest mining group in the world; it is also one of the largest enterprises in Australia, having a great influence on Australian society. One former Australian government official said BHP had strong connections in the Australian government (Garnaut 2009). BHP produced and made use of a public relations campaign against Chinalco to play up the alleged threat the Chinese company posed to Australia's national security, ultimately ensuring its deal to increase its investment in Rio Tinto was used by the opposition party to attack the government. The opposition party accused Chinalco of being backed by the Chinese Government, which it claimed had a close relationship with the ruling Labor Party. Under pressure, the Labor Party became very cautious in reviewing the deal to show that it had no inappropriate relationship with China. As a result, the approval of the Chinalco investment project was delayed and Rio Tinto turned to BHP to form a new joint venture.

Moreover, national security reviews in developed countries can easily be used by rivals of Chinese enterprises to set investment hurdles through politicising business competition. In Case No. 2, US congressman Richard Pombo put forward a resolution to suggest that approval of investment by Chinese enterprises in US oil companies should be postponed by at least 120 days. What is noteworthy is that Pombo represents the State of California, where CNOOC's competitor in 
the Unocal bid, Chevron, is headquartered. In addition, US telecommunications enterprises such as Cisco have played a role in blocking Huawei's investments in the US market through lobbying of government.

\section{Empirical analysis of factors behind blocked investment}

After theoretical analysis and case studies in previous sections, this section uses the probit model to estimate the major influential factors in deciding whether the ODI of Chinese enterprises is blocked.

\section{Data and variables}

Analysis of the blocking of China's ODI activities should include both 'blocked' (uncompleted investment) samples and 'successful' (completed investment) samples. The 'blocked' samples, as mentioned earlier, include 22 cases during the period 2005-15. Meanwhile, the 'successful' samples include 432 investment projects. For information on these investment projects, we first check the list of approved ODI projects of China's National Development and Reform Commission and retrieve basic information such as investment scale, the countries invested in and the targets of investment. Then, through corporate information disclosures and media reports, we sort out the projects with disclosed information on their investment scale and targets and which have Chinese investors holding more than 10 per cent of shares. We exclude a project if it involves a Chinese enterprise investing in another Chinese enterprise and is categorised as 'return investment' - that is, the ultimate destination of the proposed investment is the Chinese mainland.

The empirical analysis of this chapter includes the following variables that may influence the blocking of investment.

i. State-owned enterprise. This is a virtual variable: 1 represents SOE; 0 represents non-SOE. Enterprises and capital with government backing are prone to arousing the attention of authorities in the host country. For example, in its reviews, CFIUS targets whether: 1) a foreign government can substantially influence the enterprise concerned and order it to acquire US enterprises with key technologies; 2) a foreign government can provide targeted and overly generous incentives, such as grants, preferential loans and tax preferences. China's SOEs have access to government policy and resource support and are prone to accusations of threatening the host country's national security and jeopardising fair market competition; therefore, they are more likely to encounter hurdles to investing overseas. 
ii. Investment scale, with the unit being $\$ \mathbf{1}$ million. The larger the investment scale, the greater is the probability that the project will have a bearing on local affairs in the host country; therefore, it is more likely the project will receive attention from the regulators, society and media of the host country.

iii. Political risk and institutional distance. This chapter complies with the existing documents and adopts the International Country Risk Guide political risk index, released by the Political Risk Service Group, to measure the political risks in host countries. The index is a qualitative variable, covering 12 aspects, such as political stability, military intervention in politics, internal and external conflicts, corruption, law and administrative efficiency. The bigger the value, the smaller is the political risk. As mentioned in the literature review in the second part of this chapter, no consensus has been reached on measuring the influence of political risks in the host country on China's ODI. Apart from absolute institutional quality (here, this refers to political risks in the host country), the institutional distance between the parent and host countries may also play a role in whether the enterprise encounters hurdles in investing in the host country and therefore also becomes a variable, defined as the gap between the political risk index in the host country and that in China.

iv. Bilateral political relations. The indicator of bilateral political relations in the Country-risk Rating of Overseas Investment from China report (Zhang and Wang 2018), compiled by the Chinese Academy of Social Sciences, is adopted in this chapter. Good bilateral relations are conducive to the development of direct investment and serve as a lubricant for enterprises to invest and operate in host countries, thus lowering the negative impacts on international investment of the social and political risks in host countries. However, some studies also show that, given the existence of sunk costs, the worsening of international relations does not have a significant negative impact on the investment decision-making of multinationals (Davis and Meunier 2011).

v. Natural resources. This indicator is calculated based on the trade-in-goods matrix data of the UN Conference on Trade and Development and measured by the aggregate fuel and mineral exports to GDP ratio in the host country. As the world's factory and most populous country, China has a great demand for natural resources. One of the main driving forces of China's ODI is accessing stable sources of raw materials. Resources, including minerals, coal and oil, are nonrenewable. Meanwhile, resource exploitation can easily cause environmental problems and lead to corruption, thus triggering complaints from local people. 
vi. Patent. This refers to the indicator of resident applications per million population in the database of the World Intellectual Property Organization. ${ }^{1}$ Although it cannot fully reflect a country's technological level, it can, to an extent, reflect a country's technological research and development input-output level and its technological knowledge level. It is widely used in the literature as a measure of technological level. The acquisition of strategic assets, such as technology and brands, is conducive to improvement in the competitiveness of Chinese enterprises and helps them move higher in the value chain. ODI is an important way of achieving those goals. However, as Chinese enterprises increase their technology acquisition-oriented direct investment, host countries have become increasingly concerned about loss of key technologies.

vii. Invested industry. The blocking of ODI activities due to political factors may also be related to the nature of the invested industries. For instance, the French Monetary and Financial Code says that, in 11 specific industries, foreign investors in local enterprises should be subject to foreign investment review on the grounds of defending France's public order, public safety or national defence interests (US GAO 2008). The US Foreign Investment and National Security Act of 2007 also lists several economic sectors that are categorised as 'important infrastructure'. We mark industries based on the industrial classification and codes for national economic activities provided by the National Bureau of Statistics of China. According to Table 13.2, cases of blocked investment occur in agriculture, forestry, animal husbandry and fisheries, mining, telecommunications, construction, culture, sport and entertainment. We set those industries as virtual variables. If an industry is the invested industry, the variable is 1 ; otherwise, it is 0 .

viii. Other controlled variables. These include economic growth in the host country, the distance between the capital cities of two countries and the year of investment.

\section{Econometric model and regression results}

Based on the above analysis, we estimate the influence of the above-mentioned factors on whether the ODI activities of Chinese enterprises are blocked. Since whether they are blocked is a discrete choice, the estimation equation can be expressed as the following probit model (Equation 13.1).

Equation 13.1

$\operatorname{Pr}\left(\right.$ Failure $\left._{O D I_{i}}=1 \mid X_{i}\right)=\Psi\left(X_{i} \beta\right)$

1 Country ownership of patents is based on the nationality of patent applicants. 
In Equation 13.1, the dependent variable denotes the possibility of the investment being blocked-that is, 1 if the investment is blocked and 0 if the investment is completed; $i$ refers to the specific enterprise; $X$ refers to the set of all explanatory variables; $\beta$ is the coefficient of the corresponding variable; and $\Psi$ denotes the cumulative distribution function of standard normal distribution. Apart from the probit model, we also use the linear probability model (LPM) to conduct regression analysis. In the LPM, the ordinary least squares (OLS) method is used to estimate the binary choice model; since it has some problems, it is not as accurate as the probit model. ${ }^{2}$ Here, the LPM regression is introduced to serve as the comparison of the probit model estimation.

Table 13.3 provides the regression results of probit and LPM. It is found that the ownership of an enterprise is not the main factor behind its investment being blocked; however, the larger the investment scale is, the more probable it is that the investment will be blocked. Table 13.2 shows that most cases of blocked investment involve SOEs; however, regression results indicate that the ownership of an enterprise does not have a major impact on whether its investment will be blocked. This is because, in the sample interval, China's ODI activities are carried out mainly by SOEs, ${ }^{3}$ which signifies that many SOEs have already completed their ODI. As a result, the variable of 'SOE' is not significant in the statistics. However, the variable of 'investment scale' passing the 1 per cent significance test is the main factor behind the blocking of investment by Chinese enterprises; more specifically, the larger the investment scale, the more probable it is that an enterprise's ODI will be blocked. This may be because of the effect known as 'a tall tree catches the wind': projects of larger investment scale may attract more attention and become targets of attack.

The political risks in the host country and institutional distance are not significant factors influencing whether an investment project will be blocked. However, the better the bilateral political relations, the less probable it is the investment of a Chinese enterprise will be blocked in the host country. Neither the absolute institutional indicator (political risk in host countries) nor the relative institutional indicator (institutional distance) is significant in the statistics. But the significance of the variable of 'bilateral political relations' is negative and it passes the 1 per cent significance test. It is found that good bilateral relations are conducive to the entry of Chinese enterprises into local markets and to reducing resistance to Chinese investment.

2 For example: 1) there is a linear relationship between the assumptive independent variable of LPM and the probability of $Y=1$, although such relationships are often nonlinear; 2 ) the fitted value may be $<0$ or $>1$, but the probability value must be within a closed interval between 0 and 1; and 3) the disturbance term is subject to binary distribution, not normal distribution.

3 From 2006 to 2014, ODI by nonfinancial central SOEs accounted for 77 per cent of China’s total nonfinancial overseas investment stock. 
Table 13.3 Regression results of factors behind blocked investment

\begin{tabular}{|c|c|c|c|c|c|c|}
\hline & $\begin{array}{c}(1) \\
\text { Probit }\end{array}$ & $\begin{array}{c}(2) \\
\text { LMP }\end{array}$ & $\begin{array}{c}(3) \\
\text { Probit }\end{array}$ & $\begin{array}{l}(4) \\
\text { LPM }\end{array}$ & $\begin{array}{c}(5) \\
\text { Probit }\end{array}$ & $\begin{array}{l}(6) \\
\text { LPM }\end{array}$ \\
\hline \multirow[t]{2}{*}{ SOE } & 0.41 & -0.00446 & 0.537 & -0.00621 & 0.536 & -0.00659 \\
\hline & $(0.43200)$ & $(0.02330)$ & $(0.47700)$ & $(0.02310)$ & $(0.47800)$ & \begin{tabular}{|l}
$(0.02310)$ \\
\end{tabular} \\
\hline \multirow[t]{2}{*}{ Investment scale } & $0.000406^{\star \star \star}$ & $5.33 \mathrm{e}-05^{\star \star \star}$ & $0.000451^{\star \star \star \star}$ & $5.25 \mathrm{e}-05^{\star \star \star}$ & $0.000448^{\star \star \star}$ & $5.24 \mathrm{e}-05^{\star \star \star}$ \\
\hline & $(0.00013)$ & $(0.00001)$ & $(0.00014)$ & $(0.00001)$ & $(0.00014)$ & $(0.00001)$ \\
\hline \multirow[t]{2}{*}{ Political risk } & 0.00667 & -0.000213 & -0.0199 & -0.00164 & & \\
\hline & $(0.01840)$ & $(0.00105)$ & $(0.02430)$ & $(0.00129)$ & & \\
\hline \multirow[t]{2}{*}{ Institutional distance } & & & & & -0.0214 & -0.00171 \\
\hline & & & & & $(0.02430)$ & $(0.00128)$ \\
\hline \multirow{2}{*}{$\begin{array}{l}\text { Bilateral political } \\
\text { relations }\end{array}$} & $-6.681^{\star \star \star}$ & $-0.275^{\star \star}$ & $-6.597^{\star \star \star}$ & $-0.307^{\star \star \star}$ & $-6.621^{\star \star \star}$ & $-0.306^{\star \star \star}$ \\
\hline & $(2.37100)$ & $(0.11100)$ & (2.39000) & $(0.11500)$ & $(2.40100)$ & $(0.11500)$ \\
\hline \multirow[t]{2}{*}{ Natural resources } & & & 0.0131 & 0.000235 & 0.0132 & 0.000218 \\
\hline & & & $(0.03670)$ & $(0.00175)$ & $(0.03660)$ & $(0.00174)$ \\
\hline \multirow[t]{2}{*}{ Patent } & & & $0.262^{\star}$ & $0.0124^{\star}$ & $0.269^{*}$ & $0.0128^{\star}$ \\
\hline & & & $(0.13800)$ & $(0.00667)$ & $(0.14000)$ & $(0.00672)$ \\
\hline \multirow{2}{*}{$\begin{array}{l}\text { Agriculture, forestry, } \\
\text { animal husbandry } \\
\text { and fisheries }\end{array}$} & $2.080^{\star \star}$ & $0.119^{*}$ & $2.745^{\star \star \star}$ & $0.127^{\star \star}$ & $2.750^{\star \star \star}$ & $0.126^{\star \star}$ \\
\hline & (0.89200) & $(0.06060)$ & $(0.97800)$ & $(0.06030)$ & (0.97700) & $(0.06030)$ \\
\hline \multirow[t]{2}{*}{ Mining } & $1.478^{\star \star \star}$ & 0.0408 & $1.862^{\star \star \star}$ & $0.0623^{* *}$ & $1.870^{\star \star \star}$ & $0.0618^{\star \star}$ \\
\hline & $(0.55900)$ & $(0.02720)$ & $(0.62900)$ & $(0.02950)$ & $(0.63300)$ & $(0.02920)$ \\
\hline \multirow[t]{2}{*}{ Construction } & $1.991^{\star \star}$ & $0.485^{\star \star \star}$ & $2.085^{\star \star}$ & $0.397^{\star \star \star}$ & $2.099^{* *}$ & $0.399^{\star \star \star}$ \\
\hline & $(0.79500)$ & $(0.08980)$ & $(0.98200)$ & $(0.09860)$ & $(0.98300)$ & $(0.09850)$ \\
\hline \multirow[t]{2}{*}{ Telecommunications } & $2.615^{\star \star \star}$ & $0.309^{\star \star \star}$ & $2.601^{\star \star \star}$ & $0.295^{\star \star \star}$ & $2.604^{\star \star \star}$ & $0.295^{\star \star \star}$ \\
\hline & $(0.66100)$ & $(0.05270)$ & $(0.68200)$ & $(0.05250)$ & $(0.68200)$ & $(0.05250)$ \\
\hline \multirow[t]{2}{*}{ Economic growth } & -0.00834 & 0.00112 & 0.0272 & 0.003 & 0.032 & 0.00302 \\
\hline & $(0.06440)$ & $(0.00368)$ & $(0.07310)$ & $(0.00394)$ & $(0.07350)$ & $(0.00393)$ \\
\hline \multirow{2}{*}{$\begin{array}{l}\text { Distance between } \\
\text { two countries }\end{array}$} & 0.139 & 0.0165 & 0.0825 & 0.0161 & 0.0836 & 0.0161 \\
\hline & $(0.30300)$ & $(0.01940)$ & $(0.31400)$ & $(0.01940)$ & $(0.31400)$ & $(0.01940)$ \\
\hline \multirow[t]{2}{*}{ Year of investment } & $0.222^{\star \star \star}$ & $0.00685^{\star \star}$ & $0.207^{\star \star \star}$ & $0.00619^{*}$ & $0.224^{\star \star \star}$ & $0.00737^{\star \star}$ \\
\hline & $(0.07990)$ & $(0.00325)$ & $(0.07740)$ & $(0.00326)$ & $(0.07680)$ & $(0.00327)$ \\
\hline $\mathrm{R}^{2}$ & 0.5222 & 0.3246 & 0.5465 & 0.3079 & 0.5473 & 0.3083 \\
\hline
\end{tabular}

${ }^{* * *} p<0.01^{* *} p<0.05^{*} p<0.1$

Notes: The standard errors of mean are in parentheses; $R^{2}$ in the probit regression is pseudo $R^{2} ; R^{2}$ in the LPM regression is adjusted $R^{2}$.

Source: Authors' regression analysis of relevant data using Stata econometric software.

Whether a host country is rich in natural resources is not a significant factor behind blocked investment activities. But the higher the technological level of the host country, the more probable it is Chinese enterprises will have their investment blocked. The variable of 'natural resources' is positive, but not significant. The variable of 'patent' is also positive and passes the 10 per cent significance test. 
This variable is an indicator of technological level; its result shows that the higher the technological level of the host country, the more probable it is that investment by Chinese enterprises in local markets will be blocked. This is a reflection of the fact that those host countries with a relatively high technological level are worried about Chinese enterprises 'stealing' their key technologies and weakening their economic competitive edge. As a result, these kinds of host countries have blocked the entry of more Chinese enterprises.

Some industries are more prone than others to encountering investment hurdles. The significance of the variable of 'telecommunications' is positive and it has passed the 1 per cent significance test in all regressions. The significance of the variables of 'agriculture, forestry, animal husbandry and fisheries', 'mining' and 'construction' is also positive, but their significance falls remarkably, and some regressions have passed the 5 per cent significance test. This indicates that investment by Chinese enterprises in overseas telecommunications, agriculture, forestry, animal husbandry and fisheries, mining and construction industries is more likely to be blocked.

The significance of the coefficient of 'year of investment' is positive, which indicates that the probability of Chinese ODI being blocked in overseas markets has been rising in recent years.

\section{Countermeasures and suggestions for coping with blocked ODI}

The empirical analysis in this chapter shows that the larger the investment scale and the higher the technological level of the host country, the more probable it is that the investment by Chinese enterprises in overseas markets will be blocked; the better the bilateral relations, the smaller is the probability of Chinese enterprises encountering hurdles to investing in local markets. Moreover, investment by Chinese enterprises in certain industries — such as telecommunications, agriculture, forestry, animal husbandry and fisheries, mining and constructionis more likely than others to be blocked. Based on the above analysis, we offer the following suggestions for reducing investment hurdles.

First, investors should break up large-scale investment into several smaller investment programs to avoid attracting the attention of the host country government, community and media. Chinese enterprises generally lack experience in investing abroad and most do not know how to deal properly with local communities and media; they also lack transparency and are weak in terms of information disclosure, making it very difficult for the host country society to determine their investment motives and development philosophy. Therefore, Chinese enterprises should avoid making large-scale ODI; if they really need to carry out large-scale investment 
programs, they should break these into smaller-scale programs and gradually increase investment in local enterprises; they should first become noncontrolling or minority-controlling shareholders of local enterprises or collaborate and share interests with local enterprises.

Second, Chinese enterprises should invest in industries with relatively easier review procedures and avoid directly entering sensitive industries-such as telecommunications, aerospace, energy and infrastructure-that raise concerns about national security, geopolitics and national competitiveness. Foreign enterprises may encounter intervention from the government of the host country when they enter these types of industries. Therefore, Chinese enterprises should try to avoid investing in crucial industries and sensitive sectors and should first enter industries with relatively easier review procedures; they should gradually increase their investment and establish a good reputation before they start acquiring local enterprises in sensitive industries so as to ease concerns among the government and public of the host country.

Third, Chinese enterprises should improve their protection of intellectual property rights and continually increase research and development (R\&D) inputs in the host countries. In response to the concerns of host countries over the loss of key technologies, Chinese enterprises should attach importance to and enhance protection of the brands and intellectual property rights of the enterprises in which they invest and establish an insulation mechanism to ensure the security of business secrets and customer data. Meanwhile, Chinese enterprises should also provide support for the companies in which they invest so they can hire more R\&D staff, improve their research facilities and increase $R \& D$ inputs and establish relevant mechanisms to maintain and strengthen the business's independence, management stability and technological edge.

Fourth, Chinese enterprises should enhance strategic mutual trust with host countries and use political means to resolve political risks. Making their investment projects more mutually beneficial is the key to reducing the concerns of host country governments and the public. The key to expanding mutual benefits from investment in sensitive industries is enhancing the mutual trust between China and the host countries. It is the trust gap that has led to the repeated success of some interest groups in politicising the commercial projects of Chinese enterprises. Currently, whether in terms of investment scale or industrial penetration, China's ODI has reached a stage of development at which better political relations are needed to clear the barriers to business investment; political relations should facilitate business cooperation and economic relations should no longer serve as the ballast for various types of bilateral relations. China should cooperate with other countries, especially developed countries, in traditional and nontraditional security areas to 
acknowledge and resolve the security concerns of those countries instead of relying on the spillover effects of their economic and trade relations to make up for their inadequate cooperation in strategic areas.

Apart from the above suggestions, China can adopt clearer strategies in response to the political backlash triggered by its ODI activities.

First, Chinese enterprises should make more thorough preparations for coping with national security reviews; they should hire professionals and intermediaries to carry out thorough research and investigations, understand and abide by the host country's legal system, regulatory framework and review procedures and prepare documents and emergency plans for going through the review procedure. Admittedly, the expansion of the national security concept and the increasing political factors in the process of national security reviews have become an entrenched trend and it is very difficult for enterprises to predict whether their investment will trigger a national security review in the host country. While host countries have increasingly used such tools to block investment by Chinese enterprises, the fact that the outcome of a national security review cannot be legally challenged means it is difficult for Chinese enterprises to respond to a review. However, since the Sani Group successfully brought a suit against a CFIUS decision, citing procedural injustice, Chinese enterprises may be able to use legal means to protect their interests if they fully understand the legal and political rules of the host countries.

Second, in coping with market rule conflicts, Chinese enterprises, especially SOEs, should improve their transparency in accordance with international standards, actively clarify their internal structure, their relationship with the Chinese Government, their investment goals and policies and their future development plans. Meanwhile, they should become more profit-oriented in making international investment decisions; while investing in sensitive and important industries, they should avoid offering unrealistically high prices or shouldering excessively high business risks regardless of their capital utilisation efficiency or the real costs of investment-behaviour that can easily arouse suspicion from the government and public of the host countries and doubts about whether Chinese enterprises are real market players or government affiliates. At the state level, China should actively contribute to the build-up of the system of international investment governance and actively participate in the establishment of international investment rules to create a favourable environment for Chinese enterprises investing abroad.

Last but not least, Chinese enterprises should build an image of being neutral and not politically oriented to better cope with the distribution effect and local politics of the host country and avoid being overly close to any one political force (especially the incumbent government). Meanwhile, before the launch of their investment projects, they should take into consideration the distribution effect in the host country and clarify it in project contracts to properly guarantee the 
interests of different local groups. They should ensure their investment projects can serve the interests of local communities and pay special attention to the relative changes in benefits to different groups, providing more benefits to those who could be adversely affected by their projects. Moreover, Chinese enterprises should also thoroughly assess the possible reactions of local competitors and related interest groups, and establish and strengthen communication with local media and non-governmental and community organisations; and they should also focus on highlighting the mutually beneficial aspects of their cooperation with the local community to build favourable public relations.

\section{References}

Andrews, M., Bellmann, L., Schank, T. and Upward, R. (2012), Foreign-owned plants and job security, Review of World Economics 148(1): 89-117. doi.org/10.1007/s10290-0110110-1.

Bachmann, R., Baumgarten, D. and Stiebale, J. (2014), Foreign direct investment, heterogeneous workers and employment security: Evidence from Germany, Canadian Journal of Economics 47(3): 720-57. doi.org/10.1111/caje.12094.

Bandick, R. and Görg, H. (2010), Foreign acquisition, plant survival and employment growth, Canadian Journal of Economics 43(2): 547-73. doi.org/10.1111/j.1540-5982. 2010.01583.x.

Bénassy-Quéré, A., Coupet, M. and Mayer, T. (2007), Institutional determinants of foreign direct investment, The World Economy 30(5): 764-82. doi.org/10.1111/j.14679701.2007.01022.x.

Blanton, S.L. and Blanton, R.G. (2007), What attracts foreign investors: An examination of human rights and foreign direct investment, The Journal of Politics 69(1): 143-55. doi.org/10.1111/j.1468-2508.2007.00500.x.

Blonigen, B.A. and Slaughter, M.J. (2001), Foreign-affiliate activity and US skill upgrading, Review of Economics and Statistics 83(2): 362-76. doi.org/10.1162/00346530151143888.

Bode, E. and Nunnenkamp, P. (2011), Does foreign direct investment promote regional development in developed countries? A Markov chain approach for US states, Review of World Economics 147(2): 351-83. doi.org/10.1007/s10290-010-0086-2.

Capobianco, A. and Christiansen, H. (2011), Competitive neutrality and state-owned enterprises: Challenges and policy options, OECD Corporate Governance Working Papers No.1, Paris: OECD Publishing.

Davis, C.L. and Meunier, S. (2011), Business as usual? Economic response to political tensions, American Journal of Political Science 55(3): 628-46. doi.org/10.1111/j.15405907.2010.00507.x. 
European Commission Directorate-General for Trade (2013), Trade relations with the United States and Canada: TIPP Rules Group, anti-trust \& mergers, government influence and subsidies, Initial Position Papers for 1st Round Negotiations, 19 June, Brussels.

Fougner, T. (2006), The state, international competitiveness and neoliberal globalization: Is there a future beyond the competition state?, Review of International Studies 32(1): 165-85. doi.org/10.1017/S0260210506006978.

Garnaut, J. (2009), Rudd policy on China 'set by BHP', The Age, [Melbourne], 15 October.

Girma, S. and Görg, H. (2007), Evaluating the foreign ownership wage premium using a difference-in-differences matching approach, Journal of International Economics 72(1): 97-112. doi.org/10.1016/j.jinteco.2006.07.006.

Hayakawa, K., Kimura, F. and Lee, H. (2013), How does country risk matter for foreign direct investment?, The Developing Economies 51(1): 60-78. doi.org/10.1111/deve.12002.

Hemphill, T.A. (2009), Sovereign wealth funds: National security risks in a global free trade environment, Thunderbird International Business Review 51(6): 551-66. doi.org/ 10.1002/tie.20299.

Kerner, A. (2014), What we talk about when we talk about foreign direct investment, International Studies Quarterly 58(4): 804-15. doi.org/10.1111/isqu.12147.

Kirchner, S. (2012), Foreign direct investment in Australia following the Australia-US Free Trade Agreement, The Australian Economic Review 45(4): 410-21. doi.org/10.1111/ j.1467-8462.2012.00686.x.

Lankhuizen, M. (2014), The (im)possibility of distinguishing horizontal and vertical motivations for ODI, Review of Development Economics 18(1): 139-51. doi.org/10.1111/ rode. 12074 .

Lu, J., Liu, X. and Wang, H. (2010), Motives for outward ODI of Chinese private firms: Firm resources, industry dynamics, and government policies, Management and Organization Review 7(2): 223-48. doi.org/10.1111/j.1740-8784.2010.00184.x.

Organisation for Economic Co-operation and Development (OECD) (2009), Guidelines for Recipient Country Investment Policies Relating to National Security: Recommendation adopted by the OECD Council, 25 May 2009, Paris: OECD Investment Division.

Pandya, S.S. (2014), Democratization and foreign direct investment liberalization, 1970 2000, International Studies Quarterly 58(3): 475-88. doi.org/10.1111/isqu.12125.

Pinto, P.M. and Pinto, S.M. (2008), The politics of investment partisanship and the sectoral allocation of foreign direct investment, Economics \& Politics 20(2): 216-54. doi.org/ 10.1111/j.1468-0343.2008.00330.x.

Rosen, D. and Hanemann, T. (2013), China's direct investment in the advanced economies: The cases of Europe and the US, International Economic Review 1: 94-108. 
Southern Metropolis Daily (2011), Huawei dropped bid to purchase 3Leaf again for 'security concerns', Southern Metropolis Daily, 22 February.

United States Chamber of Commerce and National Foreign Trade Council (2012), Establishing rules of the road: Commercial SOEs and private actors, SOE Presentation, 4 March, Melbourne.

United States Government Accountability Office (US GAO) (2008), Laws and policies regulating foreign investment in 10 countries: Report to the Honorable Richard Shelby, Ranking Member, Committee on Banking, Housing, and Urban Affairs, US Senate, GAO08-320, February, Washington, DC: GAO.

Waldkirch, A. (2010), The effects of foreign direct investment in Mexico since NAFTA, The World Economy 33(5): 710-45. doi.org/10.1111/j.1467-9701.2009.01244.x.

Watai, R. (2013), US and Japanese national security regulation on foreign direct investment, Asia Pacific Bulletin (219)(2 July).

Wood, G., Mazouz, K., Yin, S. and Cheah, J. (2014), Foreign direct investment from emerging markets to Africa: The HRM context, Human Resource Management 53(1): 179-201. doi.org/10.1002/hrm.21550.

Zhang, M. and Wang, B. (2018), Report of Country-risk Rating of Overseas Investment from China (CROIC-IWEP) (2018), Beijing: China Social Sciences Press. 
This text is taken from The Chinese Economic Transformation: Views from Young Economists, edited by Ligang Song, Yixiao Zhou and Luke Hurst, published 2019 by ANU Press, The Australian National University, Canberra, Australia.

doi.org/10.22459/CET.2019.13 